\title{
Primary skin diseases and cutaneous manifestations of systemic diseases in swine ${ }^{1}$
}

\author{
Paula R. Pereira ${ }^{2 *}$ (D), Ronaldo M. Bianchi², Márcia E. Hammerschmitt², \\ Raquel A.S. Cruz ${ }^{3}$ (D), Kivia L. Hesse ${ }^{2}$, Luciana Sonne ${ }^{2}$ (D), \\ Saulo P. Pavarini ${ }^{2}$ (D) and David Driemeier ${ }^{2}$ (D)
}

\begin{abstract}
Pereira P.R., Bianchi R.M., Hammerschmitt M.E., Cruz R.A.S., Hesse K.L., Sonne L., Pavarini S.P. \& Driemeier D. 2020. Primary skin diseases and cutaneous manifestations of systemic diseases in swine. Pesquisa Veterinária Brasileira 40(8):579-588. Setor de Patologia Veterinária, Departamento de Patologia Clínica Veterinária, Faculdade de Veterinária, Universidade Federal do Rio Grande do Sul, Av. Bento Gonçalves 9090, Prédio 42505, Porto Alegre, RS 91540-000, Brazil. E-mail: paula.rpereira@hotmail.com

Skin diseases in pigs can negatively impact the production. They cause losses related to the death of the affected pigs, to the cost with the treatment, growth retardation and condemnations in the slaughterhouses. This study was developed to determine the frequency and describe the histopathological findings of skin diseases in pigs in different age groups through a retrospective study from 2006 to 2018. A total of 154 conclusive cases were analyzed, including skin restricted diseases (allergic dermatitis, exudative epidermitis, vesicular dermatitis, pityriasis rosea, swinepox, follicular cyst, papilloma and scrotal hemangioma) or skin lesions secondary to systemic diseases (erysipelas, porcine dermatitis and nephropathy syndrome [PDNS], bacterial septicemia and multiple hemorrhages without definite cause). The skin lesions were classified as bacterial (46.1\%), viral (26.6\%), allergic (12.3\%), neoplastic $(1.3 \%)$ and others $(13.6 \%)$. Swine erysipelas was the most frequent diagnosis (47/154), followed by PDNS (23/154), allergic dermatitis $(19 / 154)$ and exudative epidermitis $(15 / 154)$. Vesicular dermatitis $(9 / 154)$, pityriasis rosea (9/154), septicemia with cutaneous manifestations (9/154), swinepox (9/154) and multiple hemorrhages without definite cause (7/154) were also observed. Follicular cyst (3/154), hyperkeratosis without definite cause $(2 / 154)$, papilloma $(1 / 154)$, and scrotal hemangioma (1/154) were less frequently described. Of the conclusive diagnosis, age was reported in 138 cases, with the highest frequency of skin lesions observed at the inspection process during slaughter (56/138).
\end{abstract}

INDEX TERMS: Swine, dermatitis, pathology, skin lesions, pigs, Brazil.

\begin{abstract}
RESUMO.- [Doenças primárias da pele e manifestações cutâneas de doenças sistêmicas em suínos.] As doenças de pele em suínos podem impactar negativamente a produção. Estas causam perdas relacionadas à morte dos acometidos, a custo com tratamentos, atraso no crescimento e condenações nos frigoríficos. Este trabalho foi desenvolvido para determinar
\end{abstract}

\footnotetext{
${ }^{1}$ Received on May 15, 2020.

Accepted for publication on May 27, 2020.

${ }^{2}$ Setor de Patologia Veterinária (SPV), Departamento de Patologia Clínica Veterinária, Faculdade de Veterinária (Favet), Universidade Federal do Rio Grande do Sul (UFRGS), Av. Bento Gonçalves 9090, Porto Alegre, RS $91540-$ 000, Brazil. *Corresponding author: paula.rpereira@hotmail.com

${ }^{3}$ Laboratório Patologia Geral, Instituto de Biociências (Inbio), Universidade Federal de Mato Grosso do Sul (UFMS), Cidade Universitária, Av. Costa e Silva s/n, Pioneiros, Campo Grande, MS 79070-900, Brazil.
}

a frequência e descrever os achados histopatológicos das doenças de pele em suínos nas diferentes faixas etárias, através de um estudo retrospectivo no período de 2006 a 2018. Foram analisados 154 casos conclusivos, incluindo as doenças restritas a pele (dermatites alérgicas, epidermite exsudativa, dermatite vesicular, pitiríase rósea, varíola suína, cisto folicular, papiloma e hemangioma escrotal) e as secundárias a doenças sistêmicas (erisipela, síndrome dermatite nefropatia suína [SDNS], septicemia bacteriana e hemorragias múltiplas de causa não determinada). Estas foram classificadas em bacterianas $(46,1 \%)$, virais $(26,6 \%)$, alérgicas $(12,3 \%)$, neoplásicas $(1,3 \%)$ e outras $(13,6 \%)$. A erisipela suína foi a enfermidade mais diagnosticada $(47 / 154)$, seguida por SDNS (23/154), dermatite alérgica (19/154) e epidermite exsudativa (15/154). Observamos ainda dermatite 
vesicular (9/154), pitiríase rósea (9/154), septicemia bacteriana com manifestações cutâneas (9/154), varíola suína (9/154) e hemorragias múltiplas de causa não determinada (7/154). Em menor número, cisto folicular (3/154), hiperqueratose sem causa definida (2/154), papiloma (1/154) e hemangioma escrotal (1/154). Dos casos conclusivos, a idade foi informada em 138 casos, sendo a maior frequência das lesões de pele observadas na linha de inspeção, durante o abate (56/138).

TERMOS DE INDEXAÇÃO: Dermatite, patologia, lesões de pele, suínos, Brasil.

\section{INTRODUCTION}

Swine production in Brazil ranks fourth in the world for pork production and export (USDA 2019). It is considered that the Brazilian pig herd has a good sanitary condition, proven by high productivity, with rates similar to those of other countries where pig farming is also developed. Even so, the rapid and efficient diagnosis of the most varied pathologies must be prioritized (Ciacci-Zanella et al. 2016). Skin diseases in pigs can negatively impact production, because they generate treatment costs, decrease the growth rate and, sometimes, can cause the death of the animal (Turton 2001, Bender et al. 2011). Swine skin is an important by-product of refrigeration industries, as it contributes to improving the quality of some products, as well as the amount of collagen (Schilling et al. 2003). Therefore, in addition to the losses mentioned in the production, the condemning and/or impossibility of utilization of carcasses of pigs with skin lesions can also cause important economic losses (Doster 1995, Bender et al. 2011).

A variety of diseases affect the skin of pigs and can be infectious (bacterial, viral, mycotic and parasitic), or noninfectious (environmental, nutritional, hereditary and neoplastic) (Torrison \& Cameron 2019). These diseases may involve only the skin or be cutaneous manifestations of a systemic disease (Torrison \& Cameron 2019). However, studies characterizing histologically the skin lesions in swine, whether primary or secondary, as well as establishing the age affected are scarce in the literature. Thus, the objective of this study was to determine the frequency and describe the histopathological findings of skin diseases in pigs in different age groups, diagnosed from January 2006 to December 2018 in southern Brazil.

\section{MATERIALS AND METHODS}

From January 2006 to December 2018, the files of the "Setor de Patologia Veterinária" of the "Universidade Federal do Rio Grande do Sul" (SPV-UFRGS) were reviewed, and cases of pigs with skin lesions submitted for histological analysis were select. Samples of a scientific experiment or submitted to other tests that did not include histological analysis were excluded from the research. The selected cases were from pig farms and slaughterhouses. The protocols were reviewed, and the information regarding age, history, anatomopathological descriptions and final diagnosis were analyzed and compiled. Pigs were classified into five stages of production, according to Machado (2014), in maternity (1-21 days), nursery (22-61 days), growth (62-120 days), finishing (121-160 days) and adults (over 161 days). Samples from the slaughterhouses were categorized as slaughter. Gross lesions of the main diseases were standardized according to the data provided in the histories and, to represent them, figures from the SPV-UFRGS database were used. The archived paraffin-embedded blocks were searched for making histological slides that were stained by hematoxylin and eosin technique, for later histological description. In all cases, the diagnoses were based only on the histological lesions observed, without the use of complementary exams. The study included cases in which the lesion was restricted to the skin (primary) or a cutaneous manifestation to systemic diseases (secondary). In the latter case, other organs were also analyzed when subjected together the skin. As an inclusion criterion for cases of septicemia, it was considered the anatomopathological description of erythema or cutaneous cyanosis, especially in the extremities (Torrison \& Cameron 2019), and foci of necrosis in multiple organs associated with bacterial thromboembolism (Yaeger 1995). The cutaneous diseases were classified as bacterial, viral, allergic, neoplastic and "other" (when it was not possible to insert in one of the previous categories).

\section{RESULTS}

During the period of this study, 7.782 pig tissue samples were analyzed by the laboratory, of which 167 (2.1\%) corresponded to skin lesions, which included both diseases restricted to the skin and systemic diseases with cutaneous manifestations. Of the 167 cases, seven (4.2\%) were inconclusive and six (3.5\%) unsuitable for histopathological evaluation, due to scalding and dehairing resulting from the slaughter process.

Allergic dermatitis, exudative epidermitis, vesicular dermatitis, pityriasis rosea, swinepox, follicular cyst, papilloma, and scrotal hemangioma were the primary skin lesions diagnosed. While swine erysipelas, porcine dermatitis and nephropathy syndrome (PDNS), bacterial septicemia and multiple hemorrhages without definite cause were the main skin lesions secondary to systemic diseases.

When considering conclusive diagnoses, bacterial diseases accounted for $46.1 \%(71 / 154)$ of cases, and included swine erysipelas, exudative epidermitis and bacterial septicemia with cutaneous manifestations. Viral infections were also frequent $(26.6 \%, 41 / 154)$, and represented by cases of PDNS, swinepox and vesicular dermatitis. Allergic diseases accounted for $12.3 \%$ (19/154) and corresponded to cases in which the final diagnosis was suggestive of dermatitis allergic to scabies or insect bites. Neoplastic category was the less frequent $(1.3 \%, 2 / 154)$ and represented by papilloma and scrotal hemangioma. In the category "others", 13.6\% (21/154) of the cases were included, with diagnoses of pityriasis rosea, multiple hemorrhages without definite cause, follicular cyst and hyperkeratosis without definite cause. The frequencies of the main skin diseases diagnosed in this study are shown in Figure 1. Less frequent diagnoses were follicular cyst (1.9\%), hyperkeratosis without a defined cause $(1.3 \%)$, papilloma and scrotal hemangioma ( $0.6 \%$ each).

The age or production stage of the pigs was reported in 138 of the 154 conclusive diagnoses, with greater occurrence in the slaughter process $(56 / 138)$. The occurrence of the main skin diseases by pig production stage is described in Table 1 . Of the cases of follicular cysts, $2 / 3$ and $1 / 3$ were of the slaughter and adult categories, respectively. The cases of hyperkeratosis without a definite cause had no age information. Papilloma was observed in a slaughter pig and scrotal hemangioma in an adult pig.

Swine erysipelas caused by Erysipelothrix spp. was the skin disease most frequently diagnosed (47/154). Grossly, 
the disease was characterized by reddish multifocal lesions, with raised edges and a characteristic diamond shape (Fig.2A). Histologically, multifocal vasculitis was observed in the dermis and subcutaneous tissue, characterized by predominantly neutrophilic inflammatory infiltrate, surrounding and intermingling the blood vessels wall, associated with fibrinoid vascular degeneration and necrosis. There were also multifocal areas of necrosis in the dermis and subcutaneous tissue associated with fibrin deposition, as well as multifocal thrombosis and neutrophilic infiltrate in sweat gland ducts (Fig.2B and 2C).

The PDNS caused by porcine circovirus type 2 (PVC2) corresponded to $23 / 154$ cases, of which $52.2 \%$ were diagnosed in the first two years of the study, 2006 and 2007. On the skin, dark red, multifocal macules and papules have been described, which sometimes coalesce to form erythematous plaques, predominantly in the pelvic limbs, ventral and perineal region (Fig.2D). Microscopically, the lesions were characterized by dermal vasculitis, associated with inflammatory infiltrate of neutrophils, lymphocytes, plasma cells and macrophages, as well as fibrinoid vascular degeneration, sometimes with multifocal hemorrhage (Fig.2E). There was also focal ulceration of the epidermis in two cases. In the kidneys, there was a marked accumulation of fibrin and neutrophils in glomeruli and in the urinary space (fibrinosupurative glomerulitis), in

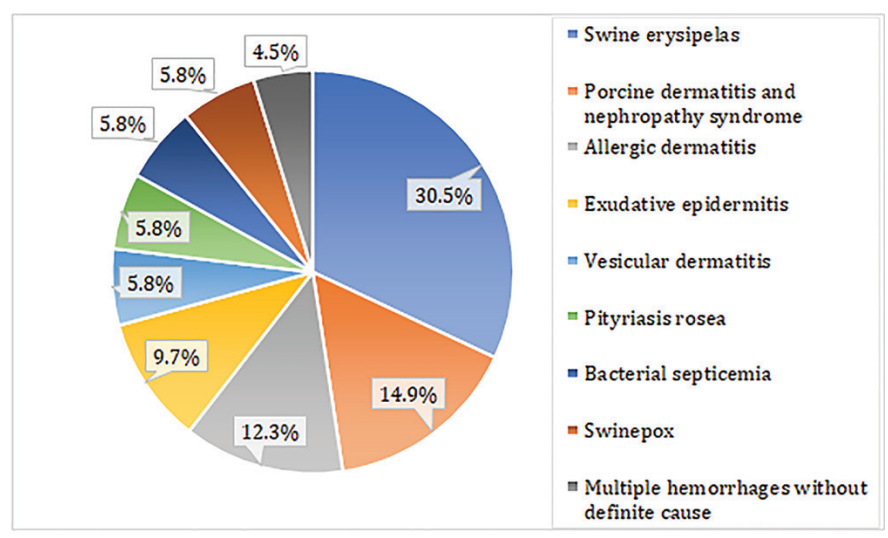

Fig.1. Frequency of the main skin diseases in swine diagnosed by the "Setor de Patologia Veterinária" of UFRGS from 2006 to 2018. addition to glomerulosclerosis and membranoproliferative glomerulonephritis. There were also marked tubular ectasia, hyaline cylinders and mononuclear interstitial nephritis (Fig.2F). In 21/23 cases, granulomatous lymphadenitis was also observed, characterized by inflammatory infiltrate of macrophages and occasionally multinucleated giant cells in the nodal parenchyma.

Allergic dermatitis corresponded to $19 / 154$ cases, and were composed by small rounded, red and raised spots (Fig.3A). Histologically, they were characterized by a multifocal eosinophilic dermatitis. The inflammatory infiltrate of eosinophils, lymphocytes and plasma cells was often observed associated with weakly basophilic and myxomatous material (edema) and, sometimes, with perivascular distribution (Fig.3B). In three cases, multifocal ulceration of the epidermis was also observed, and in none of the 19 cases, mites were seen. The $15 / 154$ cases of exudative epidermitis were characterized by marked greasy exudate and multifocal formation of crusts (Fig.3C). Microscopically, they consisted of focal areas of extensive ulceration of the epidermis, and crusted formations with marked deposition of fibrin, neutrophilic inflammatory infiltrate and coccoid bacterial aggregates. The inflammatory infiltrate also extended to the dermis and was associated with multifocal thrombosis (Fig.3D).

The cases of vesicular dermatitis (9/154) were observed only in 2015 . The disease was characterized by vesicular and ulcerative lesions in the snout, hooves and coronary band (Fig.4A). It was noted that in eight cases the vesicles had ruptured and, histologically, they were composed by discrete multifocal areas of necrosis of keratinocytes, associated with infiltrate of intact and degenerate neutrophils, fibrin deposition and coccoid bacterial aggregates. In the adjacent epidermis hydropic degeneration and moderate multifocal hyperkeratosis were also observed in keratinocytes (Fig.4B). In the case where the vesicle remained intact, there was a cystic formation covered by keratinized epithelium.

Pityriasis accounted for 9/154 of the cases, initially observed as papules on the abdomen and medial face of the pelvic limbs, evolving into circular lesions outlined by a raised red border (Fig.4C). Histologically, the lesions were characterized by marked hyperplasia of keratinocytes, which formed digitiform projections towards the dermis, multifocal intracorneal pustules, in addition to marked multifocal

Table 1. Occurrence of the main skin diseases in swine at different stages of production and slaughter histopathologically diagnosed by the "Setor de Patologia Veterinária" of UFRGS during the period from 2006 to 2018

\begin{tabular}{|c|c|c|c|c|c|c|c|}
\hline \multirow{2}{*}{ Disease } & \multicolumn{7}{|c|}{ Stages of production } \\
\hline & Maternity & Nursery & Growth & Finishing & Slaughter & Adults & $\mathrm{NI}^{*}$ \\
\hline Swine erysipelas & - & 2 & - & 1 & 43 & - & 1 \\
\hline PDNS** & - & 3 & 9 & 6 & 2 & 2 & 1 \\
\hline Exudative epidermitis & 3 & 9 & - & - & - & 1 & 2 \\
\hline Vesicular dermatitis & 9 & - & - & - & - & - & - \\
\hline Swinepox & - & - & - & - & - & - & 9 \\
\hline Multiple hemorrhages & 6 & 1 & - & - & - & - & - \\
\hline TOTAL & 24 & 17 & 22 & 12 & 53 & 5 & 14 \\
\hline
\end{tabular}

${ }^{*} \mathrm{NI}=$ not informed, ${ }^{* *}$ PDNS $=$ porcine dermatitis an $d$ nephropathy syndrome. 
inflammatory infiltrate of neutrophils, lymphocytes and macrophages in the dermis, sometimes, with perivascular distribution (Fig.4D).
In cases of bacterial septicemia (9/154), multifocal hemorrhages were observed in the dermis and subcutaneous tissue. In other organs there were multifocal thrombosis
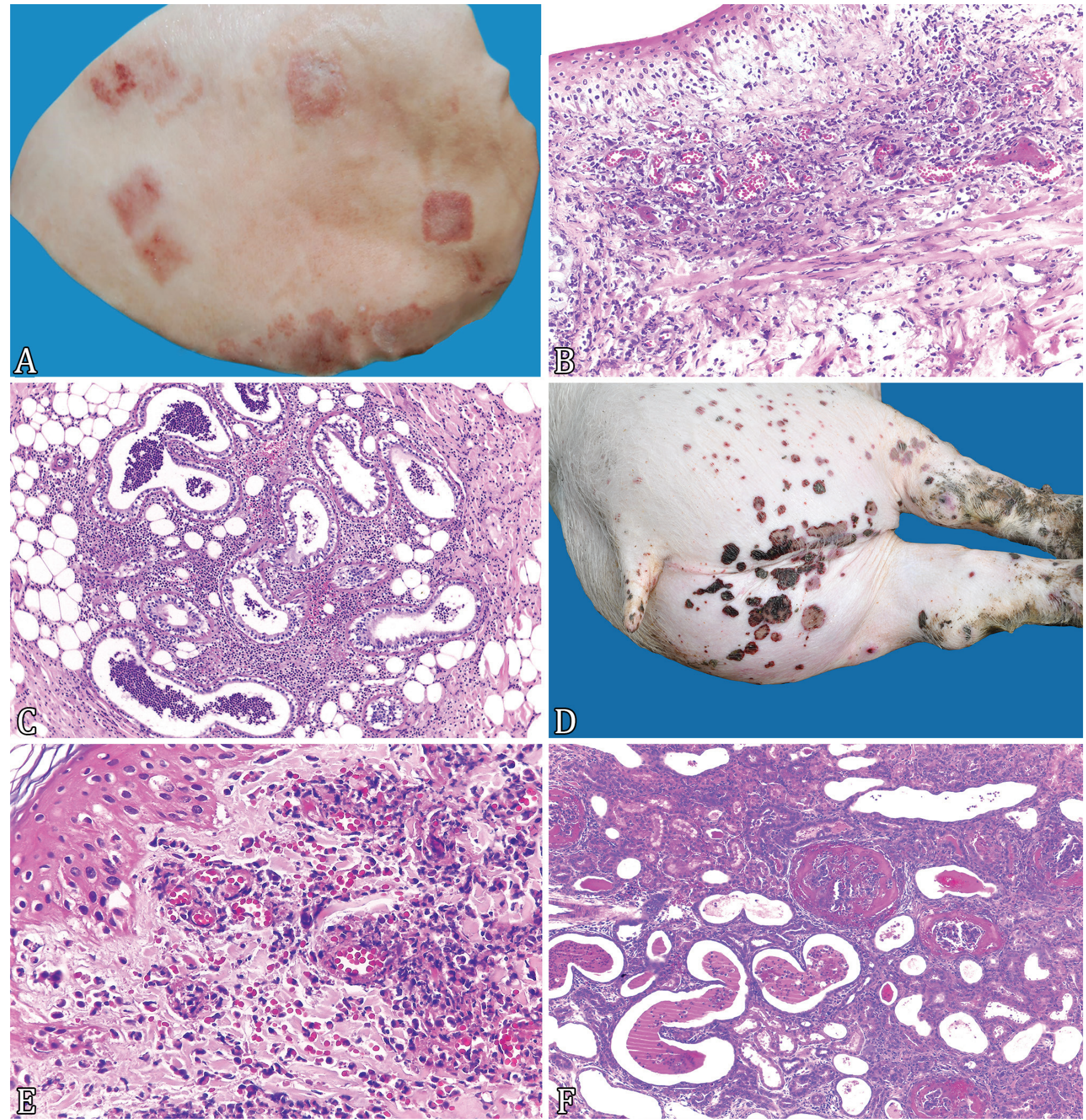

Fig.2. (A) Swine erysipelas grossly with reddish multifocal lesions, with raised edges and a characteristic diamond shape. (B) Swine erysipelas. Histologically, multifocal areas of necrosis were observed in the dermis and subcutaneous tissue, also multifocal vasculitis, fibrinoid vascular degeneration and thrombosis. HE, obj.20x. (C) Swine erysipelas. Marked inflammatory infiltrate surrounding and invading the sweat glands. HE, obj.10x. (D) Porcine dermatitis and nephropathy syndrome (PDNS). Gross appearance of the skin, dark red multifocal macules and papules in the pelvic limbs and perineal region. (E) PDNS. Microscopically, dermal vasculitis with mixed inflammatory infiltrate and fibrinoid vascular degeneration, also multifocal hemorrhage. HE, obj.40x. (F) PDNS. In the kidneys, there was a marked fibrinosupurative glomerulitis. HE, obj.10x. 
and necrosis, sometimes associated with fibrin deposition, neutrophilic infiltrate and bacterial aggregates. Swinepox, also diagnosed in 9/154 cases, was initially characterized by macules that evolved to vesicles and pustules, with subsequent formation of crusts (Fig.4E). Histologically, the lesions were composed by moderate multifocal acanthosis of the epidermis with occasional vacuolization of spinous stratum cells. Sometimes intracytoplasmic eosinophilic inclusion bodies, of approximately $3 \mu \mathrm{m}$, were also observed in keratinocytes (Fig.4F). Intracorneal pustules and necrosis of epidermis and dermis were also evidenced. Edema in the superficial dermis with infiltration of eosinophils and mast cells, compatible with allergic dermatitis was observed in eight cases. In the 7/154 cases of multiple hemorrhages without a defined cause, there was only hemorrhage and multifocal congestion in multiple organs, without associated inflammatory infiltrated or necrotic lesions.

\section{DISCUSSION}

Skin diseases can be restricted (primary) or be cutaneous manifestations of systemic (secondary) diseases. As primary, we can mention pityriasis rosea, vesicular diseases and swinepox, while secondary to erysipelas, classical swine fever (PSC) and PDNS (Torrison \& Cameron 2019). In our study, as primary skin lesions, we observed cases of allergic dermatitis, exudative epidermitis, vesicular dermatitis, pityriasis rosea, swinepox, follicular cyst, papilloma and scrotal hemangioma. While erysipelas, PDNS, bacterial septicemia and multiple hemorrhages without a defined cause were secondary. These results confirm the wide variety of skin lesions that can affect pigs. Bacterial skin diseases, including primary and secondary diseases, accounted for $46.1 \%$ of the cases in this study. Similar to that described by other authors, bacterial dermatitis is considered common, unlike fungal diseases that
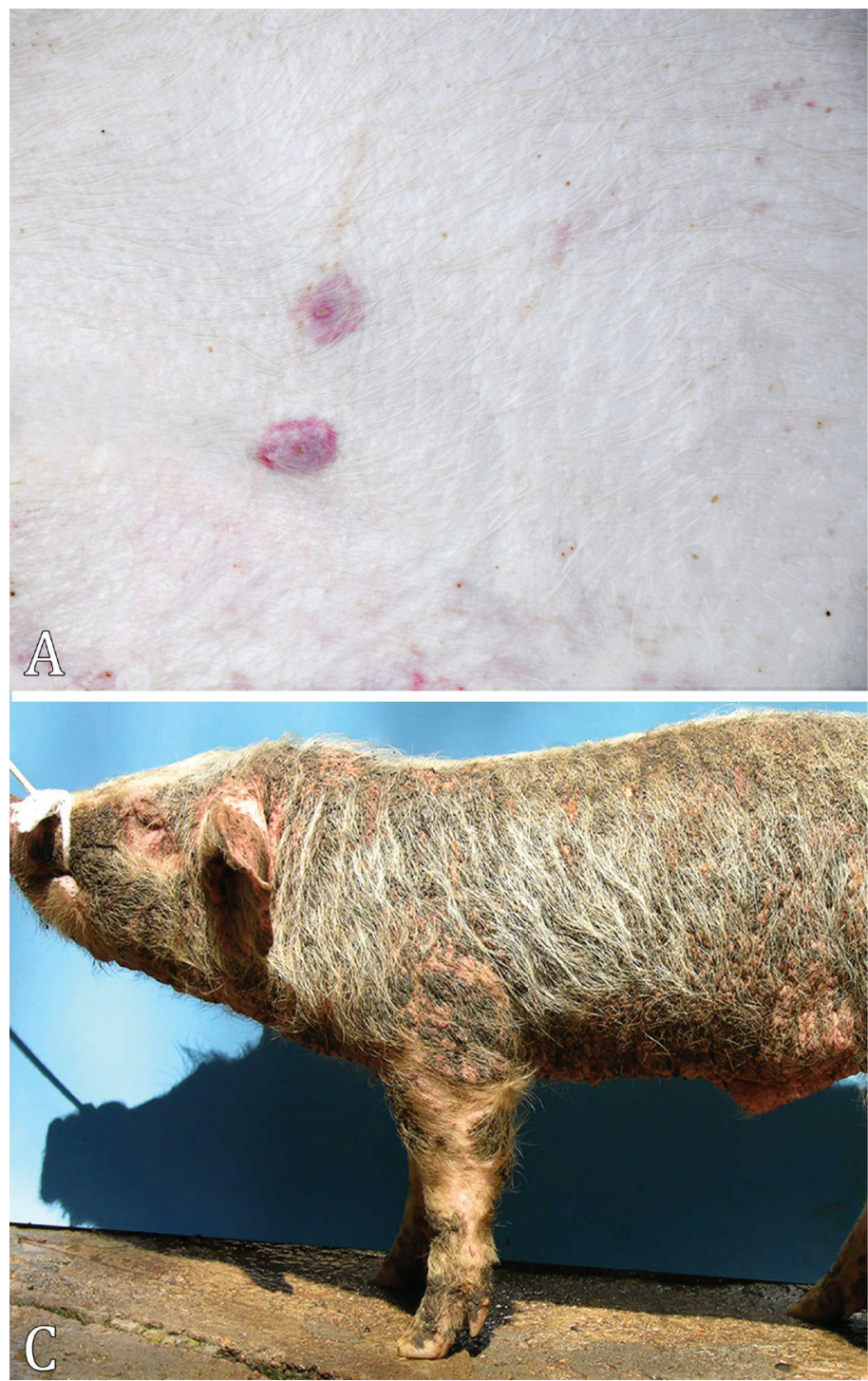
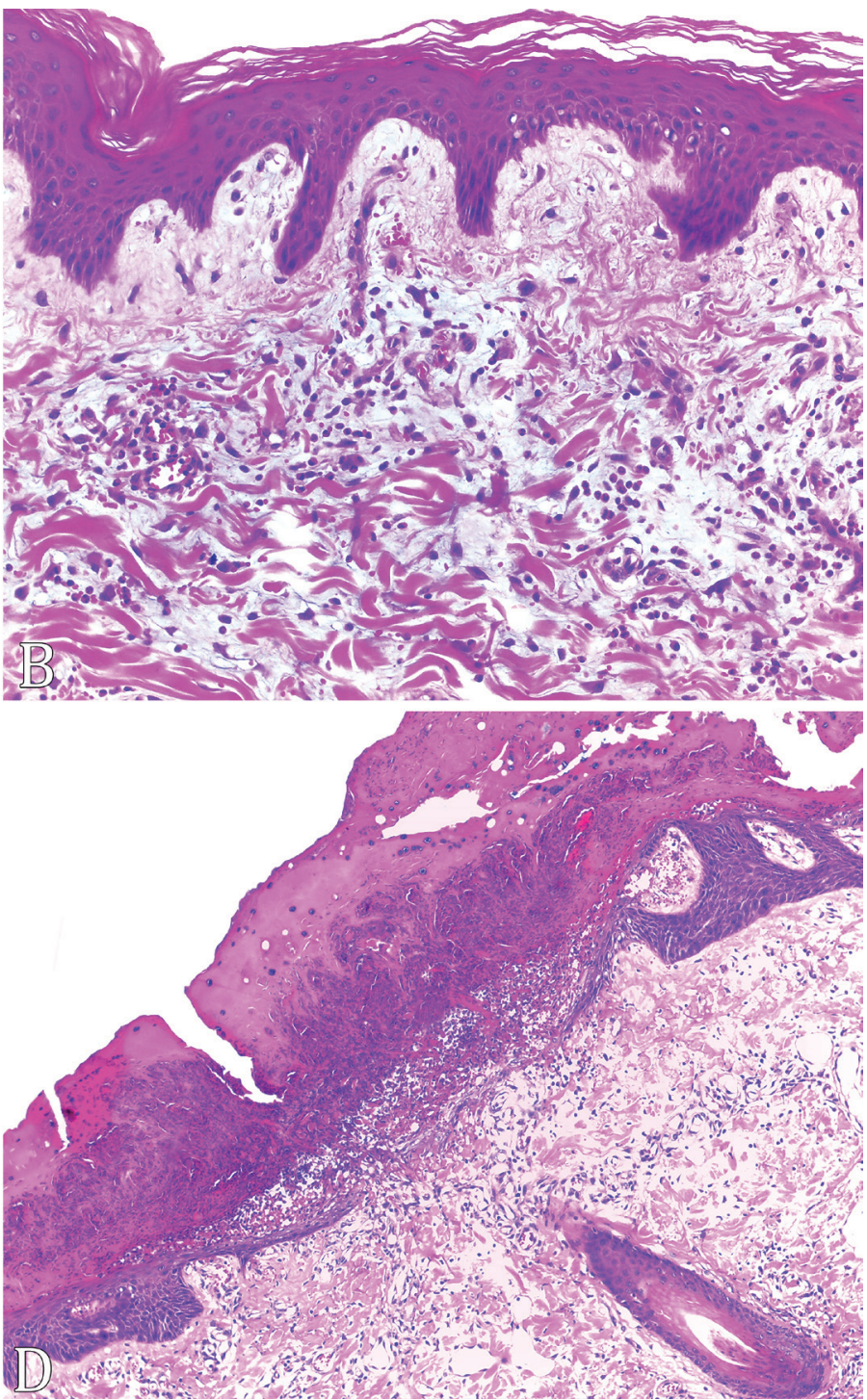

Fig.3. (A) Allergic dermatitis. Small round, red and raised spots grossly. (B) Allergic dermatitis. Multifocal eosinophilic dermatitis, sometimes perivascular, associated with edema. HE, obj.20x. (C) Exudative epidermitis. Marked greasy exudate and formation of crusts. (D) Exudative epidermitis. Microscopically observed ulceration of the epidermis, and crusted formations with marked deposition of fibrin, neutrophilic inflammatory infiltrate and coccoid bacterial aggregates. HE, obj.10x. 
are extremely rare in pigs (Jackson \& Cockcroft 2007) and were not observed in this research.

Swine erysipelas was the main diagnosis observed, and can affect pigs of all ages, however, there is a greater susceptibility for pigs between two and 12 months of age (Wood 1999). In our study, most of the cases were from pigs subjected to slaughter and can be justified by the worsening of the disease due to transport stress (Schwartz 2002). In the present study, histopathological diagnoses were analyzed, of which $30.5 \%$ corresponded to swine erysipelas. Most studies related to erysipelas include evaluations of carcasses in refrigerators and bacteriological examinations, and present a wide variation, with frequencies of $0.41 \%$ (Piva Filho et al. 2011) and $84.3 \%$ (Bender et al.2011). Brum et al. (2013), when studying swine infectious and parasitic diseases, diagnosed erysipelas in $1.4 \%$ of cases. Histological findings observed in this study were similar to those described by other authors (Barman et al. 2016, Mauldin \& Peters-Kennedy 2016), which were mainly characterized by vasculitis, degeneration and fibrinoid vascular necrosis, as well as multifocal necrosis in the dermis and subcutaneous tissue associated with fibrin deposition, thrombosis and neutrophilic inflammatory infiltrate in sweat gland ducts.

Exudative epidermitis corresponded to $9.7 \%$ of the diagnoses in this study, similar to that observed by other authors, with 5.4\% (Brum et al. 2013) and 6.25\% (Coelho et al. 2017). This disease occurs worldwide, and the main etiological agent involved is Staphylococcus hyicus (Frana \& Hau 2019), although some studies are related to a strain VA654 of Staphylococcus chromogenes (Andresen et al. 2005). In our study, the affected pigs were in the maternity and nursery, as described by Frana \& Hau (2019) in which pigs aged three to 32 days are the most affected. We observed a case in an adult pig, but it is known that finishing animals and adults are rarely affected (Barcellos et al. 2012). As described by other authors (Andresen et al. 2005, Frana \& Hau 2019) we observed ulcerative epidermitis with crust formation, marked fibrin deposition, neutrophilic inflammatory infiltrate and coccoid bacteria, as well as multifocal thrombosis in the dermis.

In the nine $(5.8 \%)$ cases of septicemia, complementary exams were not performed to establish the etiological agent. However, many agents may be involved in cases of septicemia, such as Erysipelothrix rhusiopathiae, Salmonella Choleraesuis, Actinobacillus suis, Actinobacillus pleuropneumoniae, Haemophilus parasuis, Streptococcus suis, Pasteurella multocida tipo A and Escherichia coli (Miniats et al. 1989, Sanford et al. 1990, Yaeger 1995, Del'Arco et al. 2008, Oliveira Filho et al. 2015, Torrison \& Cameron 2019). As to the stage of production, five pigs were from the maternity, two from the nursery and two from the growth. Some of the agents that can cause septicemia mainly affect pigs in these stages, ranging from 21 days to four months of age in cases of salmonellosis by Salmonella choleraesuis (Torrison \& Cameron 2019), two to 28 days in cases of A. suis (Sanford et al. 1990) and E. coli in newborn pigs (Yaeger 1995).

Viral diseases represented here by PDNS, swinepox and vesicular dermatitis, accounted for $26.6 \%$ of cases. PDNS was the second most frequent diagnosis, with half of the cases in the years 2006 and 2007, the lowest number observed in the following years is explained by the commercialization of vaccines from 2008 (Ciacci-Zanella et al. 2016). We observed
$14.9 \%$ cases of PDNS, rates higher than those observed by Segalés et al. (1998), which reports a low frequency, usually between 0.05 and 0.5\%, and Corrêa et al. (2006), in Rio Grande do Sul, which described $4.1 \%$ of PNDS cases associated with suspected necropsies of circovirus. However, the frequency of our study is very similar to that observed in the United Kingdom and other countries that had a frequency ranging from 0.25 to $20 \%$ (Gresham et al. 2000). In our study, most cases were observed in growth and finishing, agreeing, in part, with other authors, who report that this syndrome is more often described in nursery, growth and finishing pigs (Drolet et al. 1999, Gresham et al. 2000). PDNS is believed to be a type III hypersensitivity (Helie et al. 1995) and the microscopic findings observed in the kidneys, skin and lymph nodes in the cases were similar to that described in the literature, differing only in two cases, in which there was ulceration of the epidermis (Rosell et al. 2000, Wellenberg et al. 2004, Cadar 2009).

Vesicular dermatitis was associated with $5.8 \%$ of cases, a lesion that can be seen in cases of foot-and-mouth disease, swine vesicular disease, vesicular stomatitis, vesicular exanthema (Torrison \& Cameron 2019), vesicular disease associated with Senecavirus A (SVA) (Segalés et al.2017) and swine parvovirus (Kresse et al. 1985). We had information that they were negative for foot-and-mouth disease, and although there was no confirmatory examination for SVA, the involvement of this agent in our cases is suggested. These occurred in the year 2015, it was in this year and in 2014, that outbreaks occurred in Brazil of a vesicular disease of which the SVA was detected by Polymerase chain reaction (Vannucci et al. 2015, Leme et al. 2016). The affected pigs were all from the maternity, agreeing with data from the SVA outbreaks that occurred in Brazil, with the death of piglets in the first week of life (Vannucci et al. 2015, Leme et al. 2016). During the first half of 2015, of the 61 cases of swine diseases reported to the Official Veterinary Service of Rio Grande do Sul, $14.7 \%$ corresponded to idiopathic vesicular disease (Campos et al. 2016). In eight cases, the vesicles were ruptured and fibrinonecrotic dermatitis associated with bacterial colonies was observed in these areas. These histological lesions were similar to those described in the literature (Vannucci et al. 2015, Segalés et al. 2017). Segalés et al. (2017) report that ulcers begin to heal in seven days, and epithelial regeneration is usually complete within two weeks.

Swinepox corresponded to $5.8 \%$ of our diagnoses, in a study on swine diseases, it corresponded to $0.2 \%$ of the infectious and parasitic diseases diagnosed (Brum et al. 2013). This disease is caused by a poxvirus, has a wide distribution and outbreaks have already been described in São Paulo (Bersano et al. 2003, Medaglia et al. 2011), Tocantins (Bersano et al. 2003), in the Brazilian northeast (Olinda et al. 2016), Italy (Mariano et al. 2015) and India (Mech et al. 2018). The histological aspects were similar to those described by Olinda et al. (2016), of the nine cases, in eight, viral infection was associated with histological lesions suggestive of allergic dermatitis, suggesting the theory that Haematopinus suis lice and flies may be mechanical vectors for the transmission of the swinepox virus (Torrison \& Cameron 2019).

Allergic dermatitis represented $12.3 \%$ of diagnoses, these generate economic losses due to reduced growth rate, reduced feed efficiency and loss of carcass value at slaughter 
(Kessler et al. 2003, Brewer \& Greve 2019). Most of the cases corresponded to finishing and slaughter pigs, similarly to what reported by Cole (1990) in cases of hypersensitivity to insect bites in slaughter pigs and for Pedroso-de-Paiva et al.
(2003) with lesions indicative of scabies in the slaughter line. Microscopy showed eosinophilic dermatitis, predominantly perivascular, in addition to edema and ulceration of the epidermis in three cases (Cole 1990, Mauldin \& Peters-Kennedy 2016).
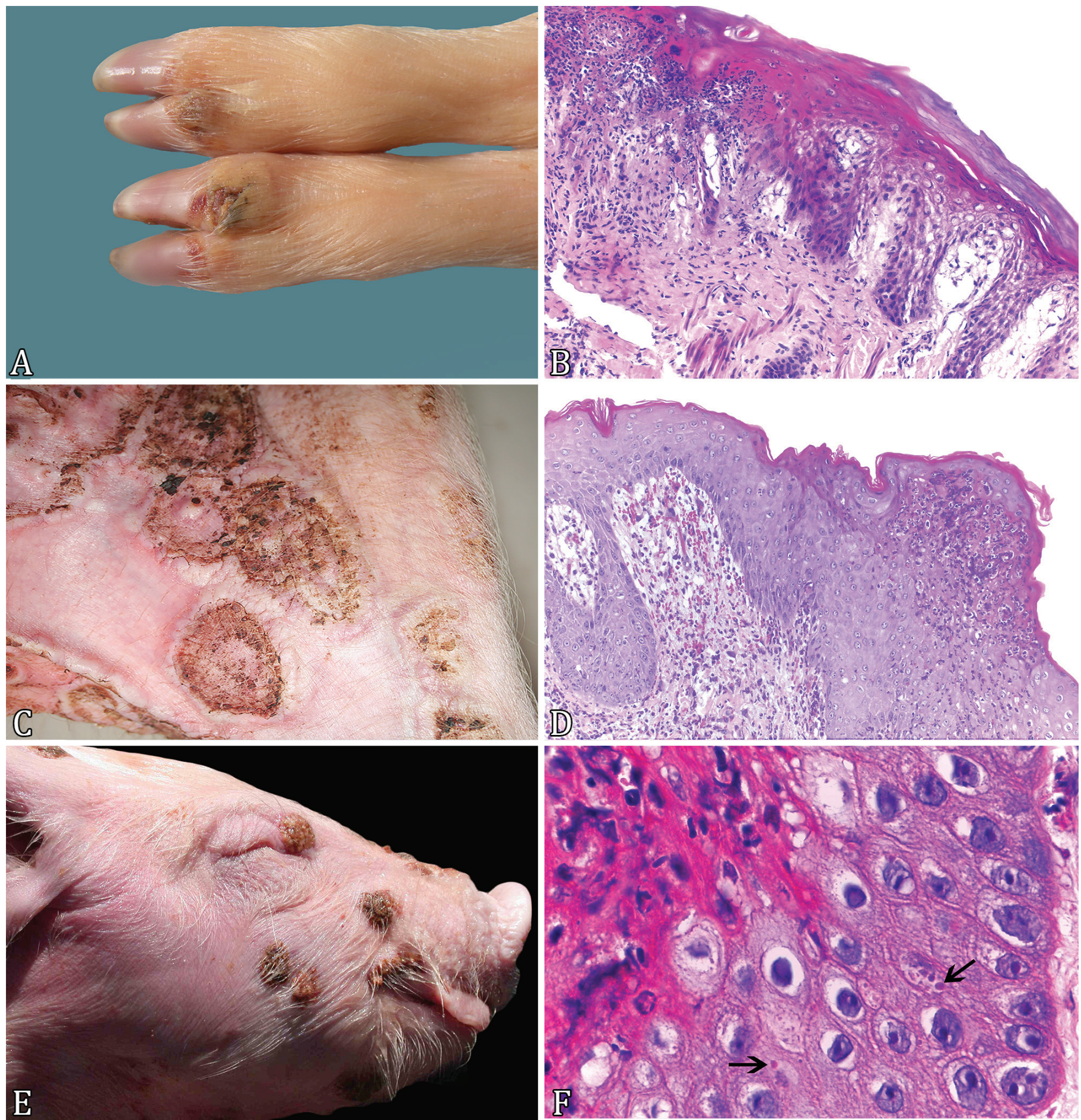

Fig.4. (A) Vesicular dermatitis. Ulcerative lesions in the coronary band in the hoof of a piglet. (B) Vesicular dermatitis. In the left corner of the figure, discrete focal necrosis of the epidermis with infiltrate neutrophils and fibrin. Adjacent epidermis hydropic degeneration in keratinocytes. HE, obj.20x. (C) Pityriasis rosea. Circular lesions outlined by a raised border on the abdomen and medial face of the pelvic limbs in pig. (D) Pityriasis rosea. Histologically, marked hyperplasia of keratinocytes and multifocal intracorneal pustules. In the dermis mixed multifocal inflammatory infiltrate. HE, obj.20x. (E) Swinepox. Vesicles, pustules and crusts on the face and ears. (F) Swinepox. Arrows show intracytoplasmic eosinophilic inclusion bodies of approximately $3 \mu \mathrm{m}$ in the cytoplasm of keratinocytes. HE, obj.100x. 
In histological sections no mites were observed, however it does not mean that any of these cases cannot be sarcoptic mange, as the agent may not be detected in histology (Brewer \& Greve 2019).

Neoplastic skin diseases represented a low number of diagnoses (1.3\%), which was expected, since neoplasms in pigs are rare (Brum et al. 2015, Torrison \& Cameron 2019). Papilloma occurred in a slaughter pig, with no information on the anatomical location, but it can affect growing pigs, especially around the neck, along the back and in the ears (Torrison \& Cameron 2019). Hemangioma was observed in the scrotum of an adult pig, corroborating with Rech et al. (2013) who described that papillomas and hemangiomas can be seen in the scrotum of old necks and are considered lesions with no clinical significance. Papilloma and scrotal hemangioma represented $0.6 \%$ each of the total skin lesions diagnosed. Brum et al. (2015), in a study on swine neoplasms, diagnosed 2/37 (5.4\%) cases of papilloma.

In the category "others", skin diseases were added that could not be inserted with bacterial, viral, allergic or neoplastic. Pityriasis rosea corresponded to $5.8 \%$ of diagnoses and affected animals in growth, as described by Kimura \& Doi (2004), different from Altrock \& Höltig (2013), who mention affecting nursery pigs. The cause of this disease is still unknown, but some authors believe that it is hereditary (Torrison \& Cameron 2019), others cite Scopulariopsis brevicaulis as a possible agent (Purchio et al. 1980). Kimura \& Doi (2004) describe three pigs and even using different methods of analysis (microbiological, histopathological, hematological and blood biochemistry) have not been able to elucidate the cause of this pathology. Histologically the lesions observed were similar to those described in the literature (Kimura \& Doi 2004, Mauldin \& Peters-Kennedy 2016).

In cases of multiple hemorrhages (4.5\%) and hyperkeratosis $(1.3 \%)$, it was not possible to confirm the diagnosis based on the information (history and anatomopathological findings) of the reports. Multiple hemorrhages in pigs can be seen in cases of coumarin poisoning (Amaral et al. 2015), purple piglet thrombocytopenia (Forster 2007), prolonged treatment with sulfas, lead poisoning, zinc phosphate, ricin, aflatoxins and ophidian accident (Sobestiansky et al. 2012). In cases of multiple hemorrhages, histology showed only hemorrhage and severe congestion. Hyperkeratosis can be observed in metabolic disorders related to nutrition, such as deficiencies of vitamin A, zinc and fatty acids, or with the formation of local calluses due to trauma associated with pressure and friction (Sobestiansky et al. 1989, Altrock \& Höltig 2013, Torrison \& Cameron 2019). During the performance of this retrospective study, we observed that some skin diseases, which are known to occur in swine farms, such as injuries from fights, sunburn and imperfect epitheliogenesis, were not diagnosed. We believe that the recognition of these and other injuries by employees and veterinarians of swine producing units, prevents them from being sent to the laboratory for analysis, therefore interfering with the diagnoses of this study.

\section{CONCLUSIONS}

This retrospective study demonstrated that the diagnosed skin diseases were more frequent in slaughter pigs and most of the bacterial origin.
The three main diagnoses were swine erysipelas, PDNS and allergic dermatitis. Followed by cases of exudative epidermitis, vesicular dermatitis, pityriasis rosea, bacterial septicemia with cutaneous manifestations, swinepox and multiple hemorrhages without a defined cause. Skin neoplasms in pigs were rare.

Acknowledgments.- The authors thank the "Conselho Nacional de Desenvolvimento Científico e Tecnológico" (CNPq) and "Coordenação de Aperfeiçoamento de Pessoal de Nível Superior" (CAPES) for supporting this study.

Conflict of interest statement.- The authors declare having no conflicts of interest.

\section{REFERENCES}

Altrock A.V. \& Höltig D. 2013. Hautkrankheiten des Schweines. Tierärztl Prax. 41(6):396-406. <https://dx.doi.org/10.1055/s-0038-1623196>

Amaral A.F., Jühlich L.M., Takeuti K.L., Rolim V.M., Gonçalves M.A., Cruz R.A.S., Driemeier D. \& Barcellos D.E.S.N. 2015. Surto de intoxicação por cumarínico em leitões de maternidade. Acta Scient. Vet. 43(supl.1):80.

Andresen L.O., Ahrens P., Daugaard L. \& Bille-Hansen V. 2005. Exudative epidermitis in pigs caused by toxigenic Staphylococcus chromogenes. Vet. Microbiol. 105(3/4):291-300. <https://dx.doi.org/10.1016/j. vetmic.2004.12.006><PMid:15708827>

Barcellos D., Alberton G.C., Sobestiansky J., Donin D.G., carvalho L.F.O.S \& Morés N. 2012. Doenças de pele, p.469-505. In: Sobestiansky J. \& Barcellos D.E.S.N. (Eds), Doenças dos Suínos. $2^{\underline{a}}$ ed. Cânone Editorial, Goiânia.

Barman N.N., Borkotoky D., Borah B., Nath A. J., Das P. \& Borah D.P. 2016. Seasonal emergence of swine erysipelas in hilly state Nagaland, Northeast India. Afr. J. Microbiol. Res. 10(48):2015-2020.<https://dx.doi.org/10.5897/ AJMR2016.8280>

Bender J.S., Irwin C.K., Shen H.G., Schwartz K.J. \& Opriessnig T. 2011. Erysipelothrix spp. genotypes, serotypes, and surface protective antigen types associated with abattoir condemnations. J. Vet. Diagn. Invest. 23(1):139-142. <https://dx.doi.org/10.1177/104063871102300126> <PMid:21217046>

Bersano J.G., Catroxo M.H.B., Villalobos E.M.C., Leme M.C.M., Martins A.M.C.R.P.F., Peixoto Z.M.P., Portugal M.A.S.C., Monteiro R.M., Ogata R.A. \& Curi N.A. 2003. Varíola suína: estudo sobre a ocorrência de surtos nos estados de São Paulo e Tocantins, Brasil. Arqs Inst. Biológico, São Paulo, 70(3):269-278.

Brewer M.T. \& Greve J.H. 2019. External parasites, p.1005-1014. In: Zimmerman J.J., Karriker L.A., Ramirez A., Schwartz K.J., Stevenson G.W. \& Zhang J. (Eds), Diseases of Swine. 11th ed. Wiley-Blackwell, Hoboken, NJ.

Brum J.S., Konradt G., Bazzi T., Fighera R.A., Kommers G.D., Irigoyen L.F. \& Barros C.S.L. 2013. Características e frequência das doenças de suínos na Região Central do Rio Grande do Sul. Pesq. Vet. Bras. 33(10):1208-1214. <https://dx.doi.org/10.1590/S0100-736X2013001000006>

Brum J.S., Martins T.B., Vielmo A., Hammerschmitt M.E., Talini R., Minozzo C.D. \& Barros C.S.L. 2015. Neoplasmas em suínos: 37 casos. Pesq. Vet. Bras. 35(6):541-546. <https://dx.doi.org/10.1590/S0100-736X2015000600009>

Cadar D., Miclaus V., Spînu M., Rus V., Cságola A. \& Tuboly T. 2009. Histopathological observations on pigs with porcine dermatitis and nephropathy syndrome. Annals of Romanian Society for Cell Biology 14(1):134-138.

Campos V.C.R., Azevedo D.L., Galvani J.W.C., Santos L.C. \& Campos F.L. 2016. Notificações de doenças em suídeos efetuadas ao serviço veterinário oficial estadual do Rio Grande do Sul no primeiro semestre de 2015. Revta Educ. Cont. Med. Vet. Zootec. CRMV-SP. 14(2):87.

Ciacci-Zanella J.R., Morés N. \& Barcellos D.E.S.N. 2016. Principais ameaças sanitárias endêmicas da cadeia produtiva de suínos no Brasil. Pesq. Agropec. Bras. 51(5):443-453. <https://dx.doi.org/10.1590/S0100204X2016000500004> 
Coelho A.C.B., Oliveira P.A., Santos B.L., Zamboni R., Silva P.E., Pereira C.M., Soares M.P., Sallis E.S. \& Schild A.L. 2017. Doenças de suínos diagnosticadas em criações de subsistência na região Sul do Brasil. Revta Invest. Vet. 16(8):56-61. <https://dx.doi.org/10.26843/investigacao.v16i8.1901>

Cole W. 1990. Ontario: suspected hypersensitivity to insect bites in market pigs. Can. Vet. J. 31(12):845. <PMid:17423711>

Corrêa A.M.R., Pescador C.A., Schmitz M., Zlotowski P., Rozza D.B., Oliveira E.C., Barcellos D.E. \& Driemeier D. 2006. Aspectos clínico-patológicos associados à circovirose suína no Rio Grande do Sul. Pesq. Vet. Bras. 26(1):9-13. <https://dx.doi.org/10.1590/S0100-736X2006000100003>

Del'Arco A.E., Santos J.L., Bevilacqua P.D., Faria J.E. \& Guimarães W.V. 2008. Swine infection by Streptococcus suis: a retrospective study. Arq. Bras. Med. Vet. Zootec. 60(4):878-883. <https://dx.doi.org/10.1590/S010209352008000400016>

Doster A.R. 1995. Skin diseases of swine. Swine Health Prod. 3(6):256-261.

Drolet R., Thibault S., D’Allaire S., Thomson J. \& Done S. 1999. Porcine dermatitis and nephropathy syndrome (PDNS): an overview of the disease. Swine Health Prod. 7(6):283-285.

Forster L.M. 2007. Neonatal alloimmune thrombocytopenia, purpura, and anemia in 6 neonatal piglets. Can. Vet. J. 48(8):855-857. <PMid:17824332>

Frana T.S. \& Hau S.J. 2019. Staphylococcosis, p.926-933. In: Zimmerman J.J., Karriker L.A., Ramirez A., Schwartz K.J., Stevenson G.W. \& Zhang J. (Eds), Diseases of Swine. 11th ed. Wiley-Blackwell, Hoboken, NJ.

Gresham A., Giles N. \& Weaver J. 2000. PMWS and porcine dermatitis nephropathy syndrome in Great Britain. Vet. Rec. 147(4):115. <PMid:10955884>

Helie P., Drolet R., Germain M.C. \& Bourgault A. 1995. Systemic necrotizing vasculitis and glomerulonephritis in grower pigs in southwestern Quebec. Can. Vet. J. 36(3):150-154. <PMid:7757919>

Jackson P.G.G. \& Cockcroft P.D. 2007. Handbook of Pig Medicine. Saunders Elsevier, London, p.112-127.

Kessler E., Matthes H.F., Schein E. \& Wendt M. 2003. Detection of antibodies in sera of weaned pigs after contact infection with Sarcoptes scabiei var. suis and after treatment with an antiparasitic agent by three different indirect ELISAs. Vet. Parasitol. 114(1):63-73. <https://dx.doi.org/10.1016/ s0304-4017(03)00098-0> <PMid:12732467>

Kimura T. \& Doi K. 2004. Clinical and histopathological findings in pustular psoriaform dermatitis (pityriasis rosea) in pigs. J. Vet. Med. Sci. 66(9):11471150. <https://dx.doi.org/10.1292/jvms.66.1147><PMid:15472483>

Kresse J.I., Taylor W.D., Stewart W.W. \& Eernisse K.A. 1985. Parvovirus infection in pigs with necrotic and vesicle-like lesions. Vet. Microbiol.10(6):525-531. <https://dx.doi.org/10.1016/0378-1135(85)90061-6><PMid:3006323>

Leme R.A., Oliveira T.E.S., Alcantara B.K., Headley S.A., Alfieri A.F., Yang M. \& Alfieri A.A. 2016. Clinical manifestations of Senecavirus A infection in neonatal pigs, Brazil, 2015. Emerg. Infect. Dis. 22(7):1238-1241. <https://dx.doi.org/10.3201/eid2207.151583><PMid:27315157>

Machado I.P. 2014. Fluxo de produção e dimensionamento de instalações, p.106-110. In: Abcs (Eds), Produção de Suínos: teoria e prática. Integrall, Brasília.

Mariano V., Nardi A., Vergari E., Carletti F., Barbieri L. \& Cardeti G. 2015. Poxvirus in a swine farm in Italy: a sporadic outbreak? Large Anim. Rev. 21(5):219-220.

Mauldin E.A. \& Peters-Kennedy J. 2016. Integumentary system, p.509-736. In: Maxie M.G. (Ed.), Jubb, Kennedy, and Palmer's Pathology of Domestic Animals. Vol 1. 6th ed. Elsevier, St Louis, Missouri.

Mech P., Bora D.P., Neher S., Barman N.N., Borah P., Tamuly S., Dutta L.J. \& Das S.K. 2018. Identification of swinepox virus from natural outbreaks in pig population of Assam. Virus Dis. 29(3):395-399. <https://dx.doi. org/10.1007/s13337-018-0464-2>
Medaglia M.L., Pereira A.C., Freitas T.R. \& Damaso C.R. 2011. Swinepox virus outbreak, Brazil, 2011. Emerg. Infect. Dis. 17(10):1976-1978. <https:// dx.doi.org/10.3201/eid1710.110549><PMid:22000394>

Miniats O.P., Spinato M.T. \& Sanford S.E. 1989. Actinobacillus suis septicemia in mature swine: two outbreaks resembling erysipelas. Can. Vet. J. 30(12):943947. <PMid:17423473>

Olinda R.G., Maia L.A., Cargnelutti J.F., Gois R.C.S., Batista J.S., Dantas A.F.M., Flores E.F. \& Riet-Correa F. 2016. Swinepox dermatitis in backyard pigs in Northeastern Brazil. Pesq. Vet. Bras. 36(6):468-472. <https://dx.doi. org/10.1590/S0100-736X2016000600002>

Oliveira Filho J.X., Morés M.A.Z., Rebelatto R., Agnol A.M.D., Plieski C.L.A., Klein C.S., Barcellos D.E.S.N. \& Morés N. 2015. Pasteurella multocida type A as the primary agent of pneumonia and septicaemia in pigs. Pesq. Vet. Bras. 35(8):716-724.<https://dx.doi.org/10.1590/S0100-736X2015000800003>

Pedroso-de-Paiva D., Morés N., Barioni Junior W., Dalla Costa O.A., Sobestiansky J. \& do Amaral A.L. 2003. Fatores de risco associados à ocorrência de sarna sarcóptica e prevalência em suínos nas fases de crescimento e terminação, na região Sul do Brasil. Ciência Rural, Santa Maria, 33(4):731-736. <https://dx.doi.org/10.1590/S0103-84782003000400023>

Piva Filho G.L., Lara L.J., Prezotto C.F., Soares B.A., Palomino B.M., Ambrósio N.A., Gibson K., Barrios P.R., Peconick A.P. \& Pereira S.M. 2011. Inspeção e julgamento das carcaças acometidas com erisipela suína em frigorífico. 38 Congresso Brasileiro de Medicina Veterinária (Conbravet). (Resumo)

Purchio A., Machado A., Gambale W., Paula C.R. \& Mariano M. 1980 Scopulariopsis brevicaulis: a possible etiologic agent of pityriasis rosea in piglets. Mycoses 23:104-111.

Rech R.R., Silva M.C., Langohr I.M., Marques M.G., Pescador C.A., Silva G.S., Dutra M.C., Brum J.S., Kramer B., Bordin L.C. \& Silva V.S. 2013. Nem tudo que parece ser, é lesão: aspectos anatômicos, não lesões, artefatos, lesões sem significado clínico e alterações post mortem encontrados na necropsia de suínos domésticos e selvagens (Sus scrofa). Pesq. Vet. Bras. 33(10):12371255. <https://dx.doi.org/10.1590/S0100-736X2013001000010>

Rosell C., Segalés J., Ramos-Vara J.A., Folch J.M., Rodriguez-Arrioja G.M., Duran C.O., Balasch M., Plana-Duran J. \& Domingo M. 2000. Identification of porcine circovirus tissues of pigs with porcine dermatitis and nephropathy syndrome. Vet. Rec.146(2):40-43.<https://dx.doi.org/10.1136/vr.146.2.40> $<$ PMid:10678809>

Sanford S.E., Josephson G.K.A., Rehmtulla A.J. \& Tilker A.M.E.1990. Actinobacillus suis infection in pigs in southwestern Ontario. Can. Vet. J. 31(6):443-447. <PMid:17423607>

Schilling M.W., Mink L.E., Gochenour P.S., Marriott N.G. \& Alvarado C.Z. 2003 Utilization of pork collagen for functionality improvement of boneless cured ham manufactured from pale, soft, and exudative pork. Meat Sci 65(1):547-553.<https://dx.doi.org/10.1016/S0309-1740(02)00247-4> $<$ PMid:22063248>

Schwartz K.J. 2002. Erysipelas: an old disease returns to the swine industry or something new? Proceedings of 33rd American Association of Swine Veterinarians, Kansas City, p.419-423.

Segalés J., Barcellos D., Alfieri A., Burrough E. \& Marthaler D. 2017. Senecavirus A: an emerging pathogen causing vesicular disease and mortality in pigs? Vet. Pathol. 54(1):11-21.<https://dx.doi.org/10.1177/0300985816653990>

Segalés J., Piella J., Marco E., Mateu-de-Antonio E.M., Espuña E. \& Domingo M. 1998. Porcine dermatitis and nephropathy syndrome in Spain. Vet. Rec.142(18):483486. <https://dx.doi.org/10.1136/vr.142.18.483><PMid:9612914>

Sobestiansky J., Mores N. \& Mori A. 1989. Epidermite exsudativa associada a deficiência de zinco em leitões de crescimento. Comunicação Técnica Embrapa-CNPSA 144, Concordia, SC. 3p.

Sobestiansky J., Mores N., Souza M.A. \& Moreno A.M. 2012. Intoxicação por minerais, produtos químicos, plantas e gases, p.567-568. In: Sobestiansky J. \& Barcellos D.E.S.N. (Eds), Doenças dos Suínos. $2^{\text {a }}$ ed. Cânone Editorial, Goiânia. 
Torrison J. \& Cameron R. 2019. Integumentary system: skin, hoof, and claw, p.292-312. In: Zimmerman J.J., Karriker L.A., Ramirez A., Schwartz K.J., Stevenson G.W. \& Zhang J. (Eds), Diseases of Swine. 11th ed. WileyBlackwell, Hoboken, NJ.

Turton J. 2001. Skin conditions in pigs. Department of Agriculture in cooperation with the ARC-Onderstepoort Veterinary Institute. Available at <https:// www.nda.agric.za/docs/Infopaks/pigskin.pdf> Accessed on Feb. 18, 2020.

USDA 2019. Livestock and Products: Annual Livestock Report Annual 2019. Foreign Agricultural Service, United States Department of Agriculture. Available at <http://www.usdabrazil.org.br/pt-br/reports/livestock-andproducts-annual-2019> Accessed on Feb. 18, 2020.

Vannucci F.A., Linhares D.C.L., Barcellos D.E.S.N., Lam H.C., Collins J. \& Marthaler D. 2015. Identification and complete genome of seneca valley virus in vesicular fluid and sera of pigs affected with idiopathic vesicular disease, Brazil. Transbound. Emerg. Dis. 62(6):589-593. <https://dx.doi. org/10.1111/tbed.12410> <PMid:26347296>

Wellenberg G.J., Stockhofe-Zurwieden N., de Jong M.F., Boersma W.J.A. \& Elbers A.R.W. 2004. Excessive porcine circovirus type 2 antibody titres may trigger the development of porcine dermatitis and nephropathy syndrome: a case-control study. Vet. Microbiol. 99(3/4):203-214. <https://dx.doi. org/10.1016/j.vetmic.2004.01.001><PMid:15066723>

Wood R.L. 1999. Erysipelas, p.419-430. In: Straw B.E., D’Allaire S., Mengeling W.L. \& Taylor D.J. (Eds), Disease of Swine. 8th ed. Iowa State University Press, Ames.

Yaeger M.J. 1995. Actinobacillus suis septicemia: an emerging disease in high-health herds. Swine Health Prod. 3(5):209-210. 